\title{
アジア太平洋の研究教育ネットワークの動向
}

\author{
菊池俊一1
}

\begin{abstract}
著者抄録 : 米国とアジアでの研究教育ネットワークの成長を解説する。まず, 1986年から1995年まで 運用されたNSFNETがインターネットの普及に果たした役割を述べる。次に1995年以降の次世代イン ターネット計画のプロジェクト, NSFの超高速基幹回線網VBNS, 大学主導のインターネット 2 プロ ジェクトと学術ネットワークAbilineについて, それぞれの目的と運用状況, NSFの助成で行われた 国際接続サービスICM とシカゴの国際接続拠点StarTAP, インターネットの国際接続プログラム HPIISの概要, アジア太平洋高度ネットワークAPANの活動とネットワーク構成について述べる。最 後に, 最近の研究教育ネットワークの話題として世界を結ぶテラビット級の研究教育ネットワーク の実現に向けた活動と国際協力計画GTRNを紹介する。
\end{abstract}

キーワード : 研究教育ネットワーク, アジア太平洋高度ネットワーク, インターネット, StarTAP, TransPAC, 韓国, 日本, アジア太平洋, NSFNET, 国際接続サービス, GTRN

\section{Trends of research and educational networks in Asia and the Pacific Regions}

\section{KIKUCHI Shunichi'}

Author Abstract: This article deals with growth in research and educational networks in the U.S. and Asia. First, it describes what roles the NSFNET had played in getting the Internet spread out. NSFNET was operated by NSF from 1986 to 1995. Secondly, it describes objectives and operation status of the following matters; the next generation Internet Project since 1995, vBNS being operated by NSF, super high speed backbone communications network, Internet 2 project initiated by 190 U.S. universities, and it outlines ICM which is an international connect service, StarTAP which is an international connect facility located in Chicago, HPIIS which is an international connect program on the Internet, network framework and activities of Asia and Pacific Advanced Network, APAN. Then it introduces the current topic, that is, cooperative activities to actualize global research and educational network of terabits scale, GTRN.

Key words: research and educational network, APAN, Internet, StarTAP, TransPAC, Korea, Japan, Asia and Pacific, NSFNET, international connect service, GTRN

\section{1. インターネットはNSFNETで普及 した}

全米科学財団（NSF）は，1986年から1995年まで 研究および教育ネットワークNSFNETを運営した。 1986年の開始時, NSFNETはまだ, 全米の5つのスー パーコンピュータセンターを $56 \mathrm{kbps}$ 基幹回線で結

1科学技術振興事業団 データベース開発部

（干102-8666 東京都千代田区四番町5-3）

Tel. 03(5214)8422 Fax. 03(5214)8470

E-mail: skikuchi@tokyo.jst.go.jp

${ }^{1}$ Japan Science and Technology Corporation, Department of Advanced Databases (5-3, Yonban-cho, Chiyoda-ku, Tokyo, 102-8666)
ぶネットワークであった。1987年6月に,NSFはネッ トワークの機能をレベルアップすることを目指し， スーパーコンピュータセンターと地域のキャンパ スネットワークの接続, ネットワークの運用管理, 地域ネットワークに対するインフォメーションサー ビスの実現を可能とするプロジェクトの公開調達 を行った。1987年11月に, ミシガン州の研究・教 育ネットワークを運営していた非営利コンソーシ アムMerit Network社の提案が採用され, IBM社と $\mathrm{MCI}$ 社の協力を得てプロダクションレベルのネッ トワーク運用管理, 通信量の増大に対処すること となる。1988年7月には基幹回線速度を $56 \mathrm{kbps} ら$ 24倍の1.5 Mbpsに増加, 1992年12月にはさらに30倍 
の45 Mbpsへの増加を完了している。 NSFNETがインターネットの世界普及をもたら すプロジェクトとなったのは, 次の点である。

(1) NSFが通信規約にISOプロトコルとX.25サポート をやめて平易な「TCP/IP」のみを採用すること を決断したこと

(2) 全米規模で24時間体制の安定し信頼できるネッ トワーク運用を実現したこと

(3) 研究·教育コミュニティのネットワークとして, 利用規約で定められる研究と教育用途の範囲内 では誰でも無料で利用できたこと

また,NSFは国際ネットワークのハブとして1991 年から1997年（当初計画は1996年）まで, 国際接続 サービス（ICM）をSprint社への委託により運用し た。米国外からのほとんどすべてのトラフィック はICM とNSFNETを中継・通過して, 米国内の研究 機関や他国との通信を自由に行っていた。

アジア太平洋地域においては, 日本, 韓国, 中 国は米国の西海岸にあるインターネットの接続拠 点を介してつながり,研究者の間で利用されていた。

\section{2. 全米情報基盤構想はうまくできた ジグソーパズル}

1990年代に入るとインターネットは, 次第に大 学や研究機関以外でも商用利用されるようになっ た。

1993年5月, NSFはコモディティなインターネッ トの通信については民間の商用インターネット . サービス・プロバイダに任せる方針のもと,NSFNET の新しいアーキテクチャを公表した。まず，地域 ネットワークのインターネット接続ならびに全米 規模のプロバイダの相互接続を進めるため,ニュー ヨーク, サンフランシスコ, シカゴ, そしてワシ ントンDCに中立な接続拠点を設け,そこでインター ネット上の経路を道案内するサーバを運用する。 そして, 選ばれた国立研究機関や大学だけに, 従 来のインターネットの水準を超えるネットワーク サービスとなる超高速基幹回線網（vBNS）を提供 する。NSFはインターネット組織の接続拠点の運 営と,vBNSの構築に専念するという内容であった。 これらは, 増大するインターネットのトラフィッ クから研究情報を分離する1つの解でもあった。

1995年, 全米各地のスーパーコンピュータセン ターを結ぶvBNSの運用がMCI社によって開始され た。当初, vBNSが利用できる組織はスーパーコン ピュータセンターの利用者と, NSFがvBNS関連プ
ロジェクトとして研究助成を行っている研究者に 限られた。開始時の基幹回線の通信容量は $155 \mathrm{Mbps}$ であった。vBNS が稼働に入った 1995 年 4 月に NSFNETの基幹回線サービスは止まった。

米国連邦政府は全米情報基盤構想の実現に向け, 1996年10月に次世代インターネット計画（NGI計 画）を発表した。100以上のサイトを結んでエンド ツーエンドで当時の100倍の速度（つまり155 Mbps 程度) で情報を処理できるネットワークを1999年 までに，そして10以上のサイトを結んで千倍の速 度（2.4 Gbps程度）で情報を処理できるネットワー クを2000年までに，それぞれ構築することを目指 した。これにはNSF, 国防総省,エネルギー省,NASA, NIHなどの政府機関が参加した。光伝送技術など 先端ネットワーク技術の研究開発を行い, 実験用 テストベッドを構築し, 重要な国家目標や業務を 達成する革新的アプリケーション (ヘルスケア, 技術計算など）の実証実験を行った。

vBNSは他の政府機関のネットワークとともに, $\ulcorner 100$ 倍の速度」と掲げられた次世代インターネッ トインフラ整備で最も重要な役割を演じることと なった。なお, vBNSはすでにその3月に, 国立研究 機関と先端研究を行う大学(目標は全部で100機関) に対してサービスを提供するため, ネットワーク の利用規約を見直していた。基幹回線の通信速度 は, 1997年には622 Mbpsに, 1999年1月には2.4 Gbps に増強された注1。

連邦政府主導のNGI計画を補完する独立したプ ロジェクトが, 大学主導のインターネット2であ る。インターネット 2 は全米で200を超す大学と研 究機関が, 産業界と共同して先端インターネット 技術とアプリケーションを開発し, 研究や高等教 育に役立てるプロジェクトである。高解像度ビデ 才を使った遠隔教育, 遠隔医療やデジタル図書館 のような高度なマルチメディア・アプリケーショ ンの実現と, それを担う通信技術を開発すること が目的である。運営と企画は, 大学で構成する先 端インターネット開発のための非営利組織UCAID が担当している。

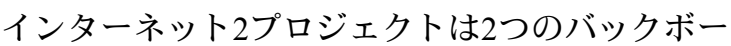
ン上で行われている。1つはインターネット2のIP 基幹伝送網となるAbilineで, Qwest社, Cisco社そし てNortel社が支援する。もう1つは, 当初のスーパー コンピュータ接続以外の先端的研究用途にもサポー

注1) 2000 年 4 月から, NSF からの助成ゼロという条件で, MCI社はvBNS+としてサービスを行っている。 
トを広げていたNSFのvBNS（vBNS+）である。

\section{NSFの国際接続プログラムHPIIS}

1997年5月NSFは，イリノイ大学シカゴ校などが シカゴに設けた, 世界と米国内の研究教育ネット ワークの接続拠点 “StarTAP” (Science, Technology and Research Transit Access Point) の運用に継続的な助成 を行うこととした。

同年, StarTAPの接続を推進するため, NSFは海 外の研究教育ネットワークとvBNSとの接続に対し て研究助成を行うプログラム（High Performance International Internet Services =HPIIS）の公募を行っ た。1998年に日本・韓国・シンガポール・オースト ラリアなどが参加するアジア太平洋高度ネットワー ク (Asia Pacific Advanced Network = APAN) をStarTAP に接続するTransPAC，ロシアを接続するMIRNET, 1999年に北欧諸国・オランダ・フランス・イスラ エルを接続するEURO-LINKの3つのリンクがHPIIS として設定された。いずれも2003年までの研究助 成が約束されている。

国際接続拠点StarTAPには, HPIIS以外にもブラ ジル, ベルギー, カナダ, 中国，アイルランド，日 本, 韓国, チリ, シンガポール, 台湾の研究教育 ネットワークが参加している。米国のAbiline,DREN (国防総省の研究ネット), ESnet（エネルギー省の 科学研究ネット), NREN (NASA研究教育ネット), NISN（NASA統合サービスネット），そしてvBNS （vBNS+）といった研究教育ネットワークとの相互 接続もここで行う。

StarTAPに接続するTransPAC回線の利用は, 当初 はvBNSの認定機関と共同研究を行っているAPAN メンバーの公的な研究機関のみに限られた。後に Abiline, NRENやNISN と相互接続し, インターネッ ト2に参加する大学との共同研究や, NASAとのプ ロジェクト実施で利用できるようになった。当初 の回線速度は35 Mbps，段階的に増速し，2001年10 月からは622 Mbps回線2本での運用を行っている。 TransPAC回線の経費は, 米国側ではNSF予算によ りインディアナ大学が, 日本側では文部科学省予 算により科学技術振興事業団がそれぞれ負担して いる。

\section{APANの活動}

APANはNSFのHPIISのために発足したコンソー シアムである。1996年3月に筑波で開催された「APEC
研究開発情報化シンポジウム」の会議で, アジア 太平洋地域にハイエンドのインターネットあるい はハイパフォーマンスの研究教育ネットワークを 確立する必要があるということが認識され, 1996 年にソウルで開かれたAPECのワーキンググループ APII会合で設立の話が進み, さらに会合を積み重 ねて, 1997年6月に関係メンバーによる覚書がまと められた。

APANは,回線などリソースを参加メンバーが持 ち寄り，人材的にもメンバーができる仕事を引き 受けるという形で構成されている。APANの活動で は, インフラとなる研究教育ネットワークの整備 に加え，3つのエリアで研究が行われている。

ネットワーク技術のエリアではQoS 注2やマルチ キャスト注3, IPv6, マルチメディアの研究活動が 行われている。

天然資源のエリアでは農業，地球観測，自然災 害の予測, 生物遺伝情報などについて, アジアの 農業や自然の研究におけるネットワークの活用を 目指す活動が行われている。生物遺伝情報にかか わる 10 以上のデータベースのミラーサイトを拡大 するBio-Mirrorの運営, インターネットビデオスト リームによる農業者教育の実施などを行っている。

利用者コミュニティのエリアでは, 遠隔教育や グリッド注 4 にる研究支援が研究されている。遠 隔教育は, 米国マサチューセッツ工科大学がシン ガポール国立大学に遠隔講義を配信するなど，大 容量の国際通信回線の整備に伴い，実用域に入り

注2) インターネットの通信では, 基本的にパケットは平 等に通信が行われる。トラフィックに優先順位を付 けようという動きが “Quality of Service”（QoS）であ る。規約は存在しているが, ネットワーク間をまた がる利用は課題となっている。

注3) インターネットでの催事中継や遠隔教育など, 特定 のグループに対して同じコンテンツを送る際に,ネッ トワーク上の中継地点で適時パケットのコピーを 作ってトラフィックを削減し,ネットワークの混雑 を避けるのがマルチキャストである。

注4) Web では, HTML 文書に対してブラウザというイン タフェースを適用することで,いろいろなところに ある文書を自分の手元に持ってきて表示する。 “HTTP”というプロトコルを規定することによって 爆発的に普及した。グリッド（Grid）はそれを拡大 したもので, HTML文書だけではなく, ネットワー ク上に分散している計算資源，人的資源，データ資 源, データベース, 大規模ストレージ, 特殊なデバ イス等のさまざまな資源を,効率良く協調して使う 手段と環境を提供する（Ian Fosterによる）。 
つつある。グリッド・ワーキンググループでは, ア ジア太平洋地域の研究機関が参加するApGridプロ ジェクトとともに, まずグリッドを動かすテスト ベッドを作るという活動を行っている。

APANメンバーが運用する主な研究教育ネット ワークの国際接続状況は次のとおりである。

・米国一日本：TransPAC回線として622 Mbps回線2 本を運用。また,ハワイ大学と東京を結ぶ $155 \mathrm{Mbps}$ の回線が計画されている。

・韓国一日本 : 韓国の情報通信部と日本の総務省 により $8 \mathrm{Mbps}$ のAPII回線が設定されている。2002 年3月に, 韓国の釜山と福岡·北九州を結ぶ, 無 中継の国際光ケーブルが建設された。APANは 日韓の連携を軸として組織化されてきた経緯も あり, この光ケーブルを利用して日韓のリンク を強化することは重要な課題の1つである。

・韓国一欧州：2001 年 12 月に,アジアと欧州域を 結ぶネットワークTEIN（Trans Eurasia Information Network）の運用が開始された。韓国のKORENと フランスのRenater2を6 Mbpsで結び, 欧州研究 ネットワークGÉANTに接続している。

そのほか, 韓国からはKORENとKREONET2が 米国向け45 Mbps回線を共有してStarTAPに接続, KORENがシンガポールのSingARENに2 Mbpsで接 続している。

・オーストラリアー米国 : 学術研究ネットワーク のAARnetがシドニーとシアトルを $155 \mathrm{Mbps}$ 回線 2本で結んでいる。うち1本はハワイを経由して いる。

・ 中国 : 研究・学術機関用のネットワーク CERNET などの国際接続点となっているドラゴン・タッ プ (DRAGONTAP) は, 米国ロサンゼルスとAPAN 東京にそれぞれ10 Mbpsの回線を設定している。

・ シンガポール：先端研究教育ネットワーク SingARENは米国サンノゼに27 Mbpで接続。APAN 域内では, 韓国KOREN回線とマレーシア科学大 学との間に衛星 $2 \mathrm{Mbps}$ 回線を運営している。

・ タイ：NECTEC が運営する ThaiSARN と日本の SINETは2 Mbpsで接続している。この回線は日本 の国立情報学研究所が共同研究のため敷設して いる。

・フィリピン：フィリピン科学技術省が運営する PHnet と日本の農林水産省研究ネットワーク MAFFINは768 Kbpsで接続している。この回線は 日本の農林水産省が研究推進のため敷設してい る。

台湾 : 中央研究院計算センターは 2002 年 1 月末
に，東京と香港にそれぞれ155 Mbpsの回線を設 定した。また, 米国に155 Mbps回線2本を設定し ている。

・WIDE : AI3プロジェクトでは, 衛星通信を国際 バックボーンとして利用したインターネット接 続をタイ, マレーシア, インドネシア, 香港な どに行っている。

APANは,メンバーが提供する国際回線の運用調 整や,アプリケーション技術の国際共同研究の実 施により,アジア太平洋地域の諸国の地域のコン ピュータネットワークと利用技術のレベルアップ に貢献している。また, 年2回のAPAN会合では, メ ンバーの研究者や技術者に研究発表, 議論ならび に技術移転の場を提供している。ネットワークと その利用分野の研究交流と人材育成を図り,アジ ア太平洋地域に研究教育ネットワークのコミュニ ティを実現しつつある。

\section{5. 世界を光で結ぶラムダネットワーク の時代へ}

中国, 韓国, オーストラリアなどの研究情報ネッ トワークは, ギガビットイーサ (ギガは10億), ラ ムダネットワーク（ラムダは光の波長単位：通信 容量は数ギガ〜数十ギガ) の時代になりつつある。

日本においても，2002年1月4日に筑波, 東京, 名 古屋, 大阪を結ぶ10 Gbps超のバックボーンである スーパーSINETが開通した。

TransPACと国立情報学研究所のSINETの米国向け 回線の容量をあわせると2 Gbps となる。TransPACは 2001年10月の増速時, シカゴ回線を光収容の国際 接続拠点 “StarLight”に接続した。九州では「玄海 プロジェクト」の名の下に, 韓国・釜山との間にギ ガビット線を設定しつつある。

5月に韓国の大田で開催された次世代インター ネットのワークショップでは, 東北アジア地域の ラムダネットワークの実現がテーマとなった。韓 国と中国の間の海底ケーブルの建設は, 数十億円 で可能と試算されている。アジア太平洋地域の研 究教育ネットワーク構成として, 中国, 日本, そ して韓国に接続拠点を置く「China-Japan-Koreaハブ 構想」が検討され始めた。

米国学術ネットワークAbilineを管理するUCAID と回線を提供しているQwest社は, 2001年10月に覚 書を更新し, 新しい 5 年間のプロジェクトに入っ た。基幹回線は光技術などの新技術が導入される。 ここでもラムダベースのネットワーク構築が進め 
られている。

カナダの非営利機関である先端インターネット 研究機構CANARIEは, カナダを横断する光伝送の 研究教育インターネット基幹回線網CA*net3を運用 している。カナダ全土の大学と政府の研究所は, 地域ネットワークを経由してCA*net3 に接続し, CA*net3はニューヨーク, シカゴ, シアトルで国際 インターネット組織と相互接続している。2002年 秋に, CA*net3の8倍のデータ転送ができるCA*net4 のサービスが開始される。

欧州のDANTEは，欧州委員会と各国の助成によ り，欧州域の研究教育ネットワークを結ぶバック ボーンサービスGÉANTを2001年12月に開始した。 GÉANTは, DANTEのTEN-155に取り代わるラムダ ネットワークで, 9区間に10 Gbps回線を, 11区間に $2.4 \mathrm{Gbps}$ 回線を運用している。12月時点で, 32か国, 28のネットワークを通して3千を超える研究・教育 機関が接続している。

2002年2月に, 北米と欧州の先端ネットワークの 関係者は, 国や地域の高速の研究教育ネットワー クを結んで世界規模でテラビット級（テラは1兆） の研究ネットワークを実現する国際協力計画GTRN （the Global Terabit Research Network）を発表した。 GTRNとして欧州と北米を結ぶ2本の $2.4 \mathrm{Gbps}$ 回線の 設定が，DANTEにより計画されている。それらの 回線は, 欧州GÉANTと米国Abilene, カナダの CA*net3，そして米国のESnetを結ぶ。

5月には, ブラッセルで世界の研究教育ネット ワークのサミットが開催され, GTRNに参加する欧 米のネットワーク関係者と政策担当者, そして日 本，韓国，中国，南米，ロシアなどのネットワー ク関係者, 約 150 人が一堂に集まり，世界を結ぶラ ムダベースのネットワーク構築に向けての議論が 行われた。

APANと米国の国際リンクTransPAC回線は, NSF からHPIISプログラムとして研究助成を得て実行さ れている。現在のHPIISが終了する2003年10月以降 の新たなポストHPIISについて, NSFを含めた関係 者での検討が行われている。当然,このネットワー
クはラムダベースのアジア一米国, 米国一欧州等 の国際接続の実現を目指すことになる。わが国の 対応については, IT戦略本部で議論が進められて いる。

\section{6. グリッドとエンドツーエンド}

GTRNで構想されているラムダネットワークの 統合は, 世界中のさまざまな研究資源を研究者が 利用するグリッドに必要なネットワーク環境の実 現を目指す。

2001年8月, NSFは, 全米4つの研究機関にテラス ケールの高性能コンピュータとストレージを設置 し，それらを結ぶプロジェクトDTF（Distributed Terascale Facility）の開始を発表した。このプロジェ クトは, 2003年4月までにイリノイ州とカリフォル ニア州に所在する4つの研究機関それぞれにLinux クラスタコンピュータとオンラインストレージを 置き, それらを40 Gbpsの光伝送路で結び, あわせ て11.6テラフロップス注5の演算能力と 450 テラハイ トのデータを蓄積できるシステム「テラ・グリッ ド」を実現する。全米の科学者や研究者は, 気象 予測や地震予知, 内燃機関の効率化, 生物学, 物 理学, 材料設計などさまざまな分野で, 研究に必 要となる情報資源を「テラ・グリッド」から入手 することができる。

カナダで構築中のバックボーンサービスCA*net4 は, 大幅な高速化にあわせて，ネットワーク利用 者がエンドツーエンドで特定の波長域を専用して 利用できる「ユーザ管理ネットワーク」という新 しい機能を盛り込む。ユーザ管理ネットワークは まず, エンドユーザにネットワーク技術の開発環 境を提供し, 研究者によるグリッド関連研究や, あるいはハイテク・カナダの通信機器メーカーに よる光伝送の技術開発を推進するという。

注5) FLOPS : Floating-point Operations Per Second。1秒あた りの浮動小数点演算。計算機の処理能力を表すめ やす。 